This is a revised personal version of the text of the final journal article, which is made available for scholarly purposes only, in accordance with the journal's author permissions. The full citation is:

Banks, C.J., Chesshire, M. and Stringfellow A. (2008). A pilot-scale comparison of mesophilic and thermophilic digestion of source segregated domestic food waste. Water Science and Technology 58(7), 1475-1481. DOI 10.2166/wst.2008.513

http://www.iwaponline.com/wst/05807/wst058071475.htm

\title{
A pilot-scale comparison of mesophilic and thermophilic digestion of source segregated domestic food waste
}

\author{
Charles J Banks ${ }^{1}$, Michael Chesshire ${ }^{2}$ and Anne Stringfellow ${ }^{1}$ \\ ${ }^{1}$ School of Civil Engineering and the Environment, University of Southampton, Southampton \\ SO17 1BJ, UK (E-mail: cjb@soton.ac.uk) \\ ${ }^{2}$ Greenfinch Ltd, The Business Park, Coder Road, Ludlow SY8 1XE, UK
}

\begin{abstract}
Source segregated food waste was collected from domestic properties and its composition determined together with the average weight produced per household, which was $2.91 \mathrm{~kg}$ per week. The waste was fed over a trial period lasting 58 weeks to an identical pair of $1.5 \mathrm{~m}^{3}$ anaerobic digesters, one at a mesophilic $\left(36.5^{\circ} \mathrm{C}\right)$ and the other at a thermophilic temperature $(56$ $\left.{ }^{\circ} \mathrm{C}\right)$. The digesters were monitored daily for gas production, solids destruction and regularly for digestate characteristics including alkalinity, $\mathrm{pH}$, volatile fatty acid (VFA) and ammonia concentrations. Both digesters showed high VFA and ammonia concentrations but in the mesophilic digester the $\mathrm{pH}$ remained stable at around 7.4, buffered by a high alkalinity of 13,000 $\mathrm{mg} \mathrm{l}^{-1}$; whereas in the thermophilic digester VFA levels reached 45,000 $\mathrm{mg} \mathrm{l}^{-1}$ causing a drop in $\mathrm{pH}$ and digester instability. In the mesophilic digester volatile solids (VS) destruction and specific gas yield were favourable, with $67 \%$ of the organic solids being converted to biogas at a methane content of $58 \%$ giving a biogas yield of $0.63 \mathrm{~m}^{3} \mathrm{~kg}^{-1} \mathrm{VS}$ added. Digestion under thermophilic conditions showed potentially better VS destruction at 70\% VS and a biogas yield of $0.67 \mathrm{~m}^{3} \mathrm{~kg}^{-1}$ $\mathrm{VS}_{\text {added }}$, but the shifts in alkalinity and the high VFA concentrations required a reduced loading to be applied. The maximum beneficial loading that could be achieved in the mesophilic digester was $4.0 \mathrm{~kg} \mathrm{VS} \mathrm{m}^{-3} \mathrm{~d}^{-1}$.
\end{abstract}

Keywords: Kitchen waste, mesophilic, thermophilic, volatile fatty acids, food waste

\section{INTRODUCTION}

Alternative processing technologies for biodegradable municipal waste (BMW), such as anaerobic digestion, offer some potential for recovery of value from this material by producing soilconditioning compost and biogas. There is rising interest in the technology in the UK due to the increasing energy costs associated with the processing of wet waste, the requirement to meet the targets of the landfill directive (EC, 1999), the regulations for the disposal of animal by-products (EC, 2005), and the rapidly increasing costs of landfill.

There are many examples of the use of anaerobic digestion (AD) for the treatment of BMW recovered from household waste as part of a mechanical-biological treatment process. Both 'wet' and 'dry' anaerobic technologies have been used for the biological stage (Mata-Alvarez, 2003). There are also examples of recovery of source segregated biodegradable wastes which are a mixture 
of kitchen and garden wastes (Archer et al, 2005), but there are very few reports of AD plants operating entirely on the source segregated food waste fraction arising from domestic properties.

One of the possible reasons for this is that while food waste is an energy-rich substrate, there are some potential difficulties associated with its digestion which arise from its composition. The high protein content of food waste typically gives a high nitrogen content on hydrolysis, which leads to elevated concentrations of ammonia or ammonium ion in the digester. The distribution of the two species and their relative toxicity is $\mathrm{pH}$ dependent, with the more toxic form dominating at higher $\mathrm{pH}$ (Mata-Alvarez, 2003). High ammonia concentrations are also often associated with high volatile fatty acids (VFA) (Banks, 1994), although the ammonia provides alkalinity through the formation of ammonium carbonate, which helps to buffer the system allowing operation under these conditions (Gerardi 2003). There is still uncertainty as to the concentration at which ammonia becomes inhibitory and this is reflected in the various values given in the recent literature. According to Mata-Alvarez (2003), inhibition occurs at total ammonia concentrations of $1200 \mathrm{mg} \mathrm{l}^{-}$ 1 and above. Hartmann and Ahring (2005) showed ammonia inhibition begins at free ammonia concentrations above $650 \mathrm{mg} \mathrm{l}^{-1} \mathrm{NH}_{3}-\mathrm{N}$, whereas Angelidaki et al. (2005) in a study of 18 full-scale biogas plants in Denmark co-digesting manure and organic waste only found decreases in efficiency when total ammonia was higher than $4000 \mathrm{mg} \mathrm{l}^{-1} \mathrm{NH}_{3}-\mathrm{N}$. It was recommended (Mtz-Viturtia, 1995) that wastes with $\mathrm{C}: \mathrm{N}$ ratios lower than 10 should not be treated in one-phase systems at loading

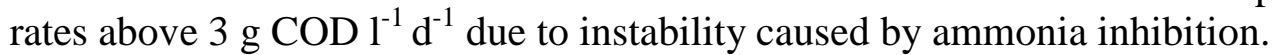

The aim of the research was to compare the mesophilic and thermophilic digestion of source segregated domestic food waste using two $1.5 \mathrm{~m}^{3}$ pilot-scale anaerobic digesters operated in parallel in an identical manner in all respects other than temperature. In practice this was not entirely possible, as instability due to the build-up of VFA and a lowering of $\mathrm{pH}$ in the thermophilic digester required the loading to this digester be reduced part way through the trial

\section{MATERIALS AND METHODS}

Waste collection and preparation. The research used source segregated food waste which was collected weekly from domestic properties in Burford Village, Shropshire, UK together with some catering wastes from a restaurant and cafe. The householders were provided with plastic bags in which the food waste was placed. These were weighed, split open and any contaminants removed before the contents were equally divided and blended with recycled digestate taken from the thermophilic and mesophilic digesters in separate storage tanks. Each mixture was further blended and kept mixed in the buffer storage tanks by recirculation through a macerator pump.

Digestion plant. The mesophilic and thermophilic digesters were identical in terms of size, shape and mechanical equipment as shown in Plate 1 and Figure 1. Each comprised a $1 \mathrm{~m}^{3}$ buffer storage tank; a $1.5 \mathrm{~m}^{3}$ closed digestion tank with gas recirculation mixing and an internal heater; a $1 \mathrm{~m}^{3}$ digestate storage tank; and a volume-calibrated bell over water gas collector. A 30-channel data logger (DT500, Datataker Ltd, Rowville, Australia) was used to record the output from thermocouples placed in the feed tank, the collection tank, and an array of 10 positioned in each digester at different levels within the vessel. Temperatures were logged at 10 minute intervals. 


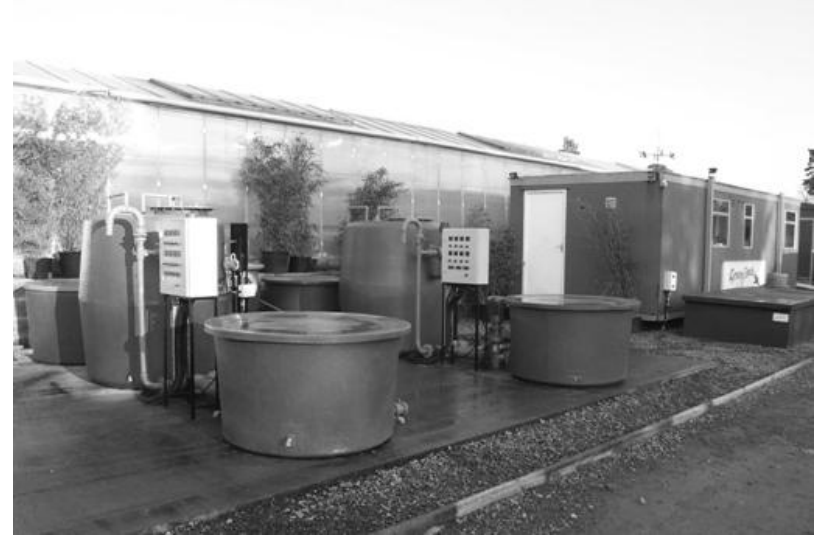

Plate 1. Pilot scale digesters used in the study

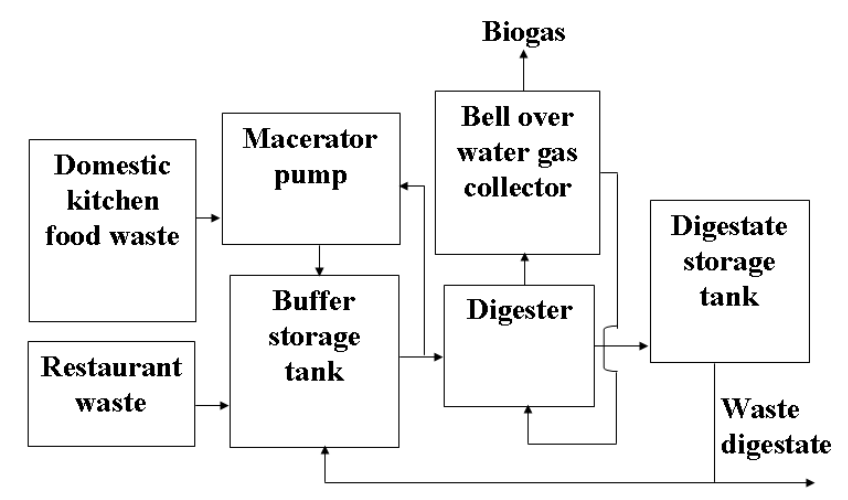

Figure 1. Schematic flowsheet of the plant

Digester feeding regime. The blended substrate was pumped batchwise 4 times a day into both the mesophilic and thermophilic digesters to guarantee a minimum residence time without bypass of six hours, and a nominal retention time of 28 days based on the food waste volume (assuming a density of $1.03 \mathrm{~kg} \mathrm{l}^{-1}$ when blended), at a design loading of $4 \mathrm{~kg} \mathrm{VS} \mathrm{m}^{-3} \mathrm{~d}^{-1}$. Before each feed a volume of digestate equal to that of the feed was pumped from each digester into its digestate storage tank. The feeding and monitoring period extended over 58 weeks to take into account of seasonal variations in the waste collected.

Sampling and analysis. The digestate and mixed feed were analysed for total solids (TS) and volatile solids (VS) using a gravimetric determination (APHA, 2005). Elemental composition of food waste and digestate was determined using an elemental analyser (FlashEA 1112, Thermo Finnigan, Italy) following the manufacturer's methods. VFA concentration and alkalinity were measured by titration of a $20 \mathrm{ml}$ filtered sample to $\mathrm{pH} 4$ with $0.1 \mathrm{M} \mathrm{HCl}$; the sample was then boiled for 3 minutes and back titrated with $0.01 \mathrm{M} \mathrm{NaOH}$ to $\mathrm{pH} 4$ and 7. The VFA acetic acid equivalent $\left(\mathrm{mg} \mathrm{l}^{-1}\right)$ was calculated as the volume $(\mathrm{ml})$ of sodium hydroxide titrated from $\mathrm{pH} 4$ to $\mathrm{pH} 7 \times 87.5$. VFA concentrations were also measured using gas chromatography. The concentration of ammonia and other nutrients such as nitrate, phosphate and potassium were measured using a Dr. Lange test kits (Hach Lange Ltd, Manchester, UK). Methane concentration in the biogas was measured using a gas analyzer (Model GA2000, Geotechnical instruments, Leamington Spa, UK).

\section{RESULTS AND DISCUSSION}

\section{Food waste collection and characteristics of the material}

On average $2.94 \mathrm{~kg}$ food waste per household was collected every week. The average TS of the waste was $23 \%$ of which VS was $92 \%$. The elemental composition of C, N, H, S, O was 55.52, $3.94,8.53,0.22,29.1 \%$ respectively, accounting for $97.3 \%$ of the VS makeup and giving a carbon to nitrogen ratio of $14: 1$.

The average composition of the food waste was determined on two occasions from a sample of $10 \%$ of the weekly collected weight. Over $60 \%$ of the material was composed of uncooked fruit and vegetable waste; other major components were bread, tea bags, cooked meat and cooked vegetables. A particle size analysis was undertaken on 100 samples of the shredded food waste, blended mixedfeed and digestate and showed that most particles were less than $2 \mathrm{~mm}$ thick, and none were greater than $12 \mathrm{~mm}$ thick (Figure 2). 


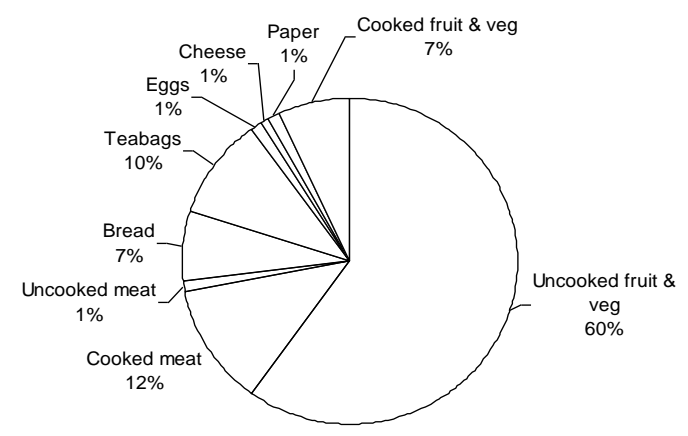

a. Proportion of food waste components

Figure 2. Food waste properties

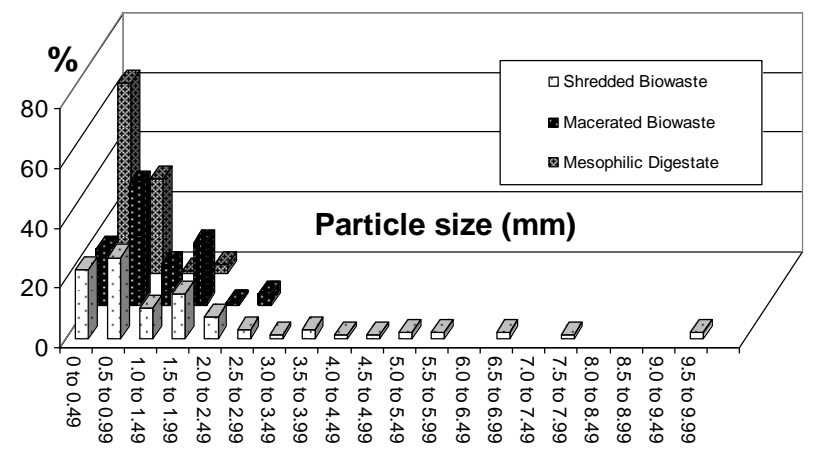

b. Frequency of particle size thickness (mm) of 100 samples of shredded raw food waste, mixed feed and digestate.

The figure of $2.94 \mathrm{~kg}$ household ${ }^{-1}$ week $^{-1}$ reflects UK Government statistics: the report 'Waste Not, Want Not' (2002) estimated food waste to be $17 \%$ of total household waste, equivalent to $3 \mathrm{~kg}$ household $^{-1}$ week $^{-1}$. These figures are also in agreement with a survey to estimate the total organic food waste generated by householders in Moray, Scotland, where an average of $2.91 \mathrm{~kg}$ of organic kitchen waste per week was measured (Jones, 2002). More recent studies on separate food waste collection in the UK (Hogg et al., 2007) have proposed values nearer to $4.0 \mathrm{~kg}$ household ${ }^{-1}$ week $^{-1}$.

\section{Digester assurance testing}

The average temperature of the thermophilic digester was $56.0^{\circ} \mathrm{C}\left(+/-0.21^{\circ} \mathrm{C}\right)$; the average temperature for the mesophilic digester was $36.5^{\circ} \mathrm{C}\left(+/-0.28^{\circ} \mathrm{C}\right)$. There were only slight variations between thermocouple readouts at different depths, showing that the mixing and heating systems were very effective at achieving a constant environment within the digester vessel. The mixing of the digesters was also confirmed using a lithium tracer test. The results from this are shown in Figure 3 which compares the experimental dilute-out curve with the theoretical model curve $\mathrm{C}=$ C0. $e^{-t / H R T}$ over a 750 hour period, and shows that uniform dispersion of the tracer in the reactor took place within 30 minutes.

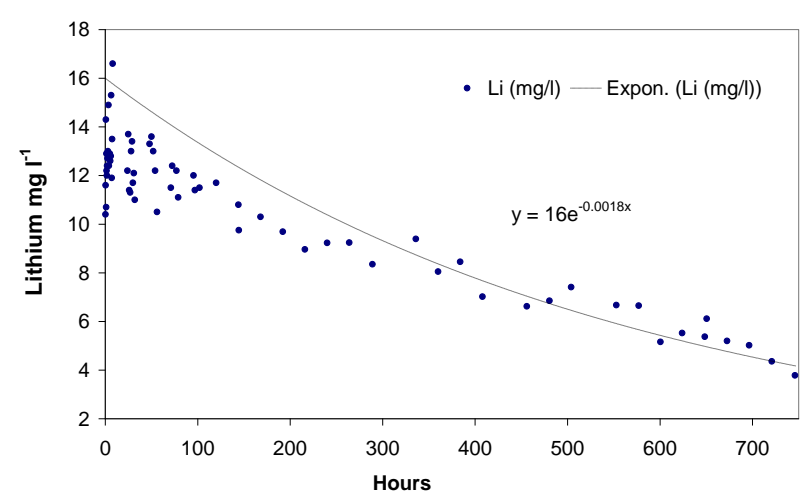

a) Lithium tracer dilute curve

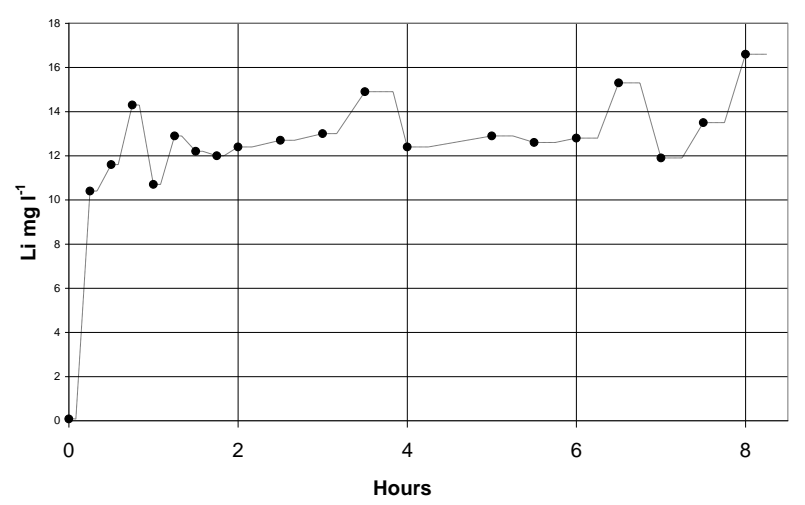

b) Dispersion of Lithium in the digester

Figure 3. Results of tracer studies

In both digesters biogas production varied throughout the year in response to operational changes. Both digesters had a tendency to develop high levels of VFA and ammonia in the digestate liquor, 
and in the case of the thermophilic digester this had to be controlled by lowering the loading rate and increasing the retention time part way through the trial.

\section{Digestion trials}

Mesophilic digester. The mesophilic digester was started at a mean retention time of 31.5 days and a specific volatile solids loading rate of $4.1 \mathrm{~kg} \mathrm{VS} \mathrm{m}^{-3} \mathrm{~d}^{-1}$. The retention time was reduced over a number of weeks to 20 days (specific loading rate of $5.72 \mathrm{~kg} \mathrm{VS} \mathrm{m}^{-3} \mathrm{~d}^{-1}$ ) but this loading rate was found to be too high, causing accumulation of VFAs and $\mathrm{pH}$ depression.

The mesophilic digester produced on average $4.4 \mathrm{~m}^{3} \mathrm{~d}^{-1}$ of biogas comprising $59 \%$ methane. A biogas production of $140 \mathrm{~m}^{3}$ per wet tonne of kitchen waste was achieved, a high value considering the total solids content of the material was only $23 \%$; this was compensated for, however, by a VS destruction rate of $67 \%$ resulting in a digestate total solids of $5.5 \%$ with VS of $75 \%$. There was an initial rise in digester VFA concentration reaching a maximum of $27,400 \mathrm{mg} \mathrm{l}^{-1}$ after 35 weeks of operation. These high VFA levels did not appear to interfere greatly with gas production or solids destruction. The high ammonia concentration of around $5200 \mathrm{mg} \mathrm{l}^{-1}$ added to the alkalinity of the system which, expressed as bicarbonate, averaged $13900 \mathrm{mg} \mathrm{l}^{-1}$. This high alkalinity was sufficient to buffer the VFA resulting in a pH between 7.3 and 7.7. To reduce the level of VFA and ammonia some of the digestate recycle was replaced with water. This reduced the VFA concentration which then stabilised between 7000-12,000 $\mathrm{mg} \mathrm{l}^{-1}$ with a lower ammonia concentration of around $3000 \mathrm{mg}$ $1^{-1}$ from week 39 onwards. Key parameters as weekly average values are shown in Figure 4.

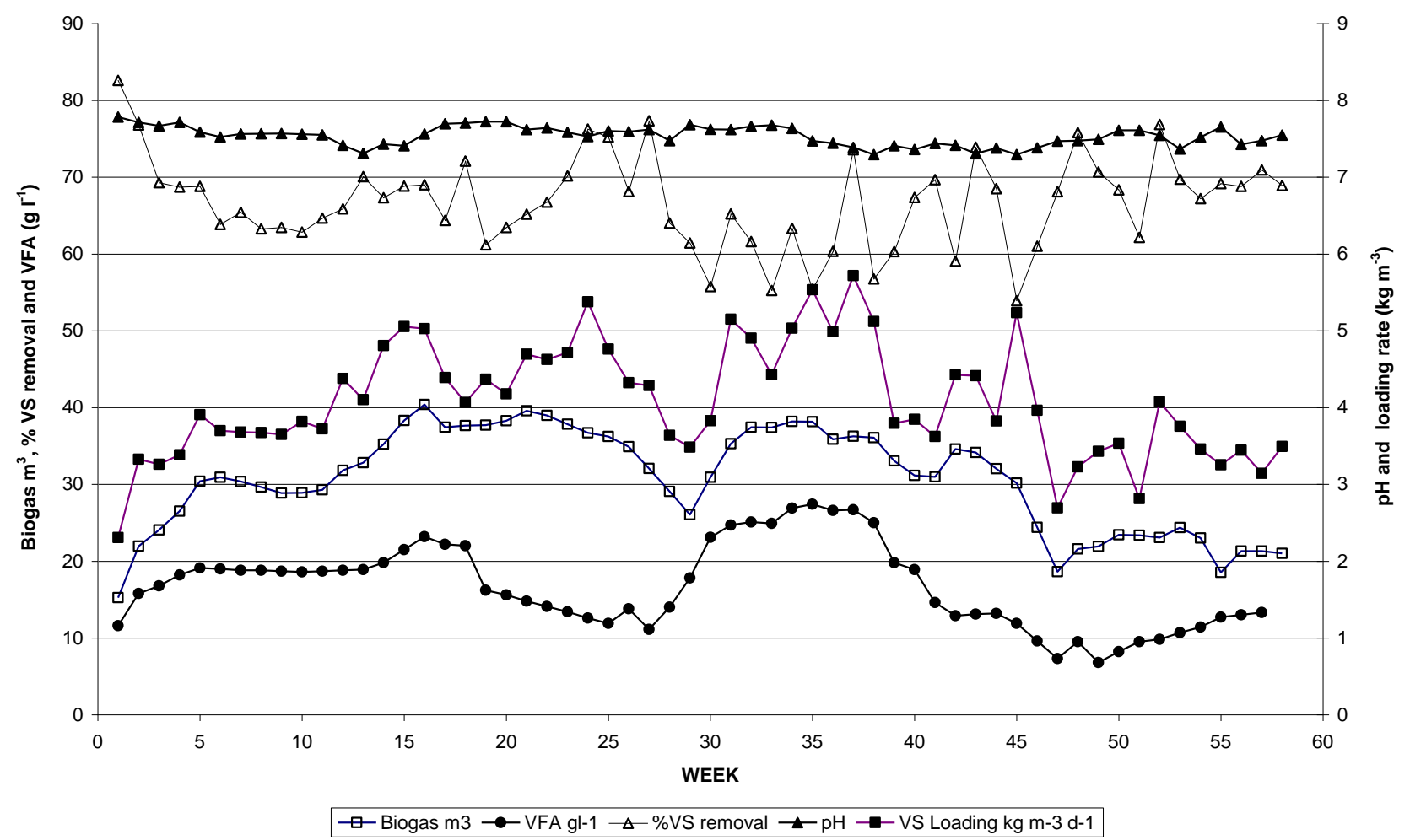

Figure 4. Key operational parameters from the mesophilic digester over the 58 week trial

Thermophilic digester. The mean hydraulic retention time was approximately 27 days over the first 25 weeks of the trial, and during the period of low loading this retention period was maintained by the addition of water to compensate for the reduced volume of food waste being added. The digester produced on average $3.1 \mathrm{~m}^{3} \mathrm{~d}^{-1}$ biogas and $58 \%$ methane. This overall lower efficiency of the digester over the trial period can be explained by the lower average load applied to the digester in 
response to very high VFA concentrations accumulating in the digester mixed liquor, which reached a level of around $40,000 \mathrm{mg} \mathrm{l}^{-1}$ by week 25 . The feed to the digester was stopped in week 27 and then resumed at a lower loading of around $1 \mathrm{~kg} \mathrm{VS} \mathrm{m}^{-3} \mathrm{~d}^{-1}$ in week 29 and continued at this loading until week 39. During this time the biogas production dropped from around $30 \mathrm{~m}^{3}$ week $^{-1}$ to between $5-10 \mathrm{~m}^{3}$ week $^{-1}$ and the VFA concentration reduced to around $14,000 \mathrm{mg} \mathrm{l}^{-1}$. The loading was then gradually increased again to $3.0 \mathrm{~kg} \mathrm{VS} \mathrm{m}^{-3} \mathrm{~d}^{-1}$ by week 47 , and over the last 10 weeks of the trial averaged $3.6 \mathrm{~kg} \mathrm{VS} \mathrm{m}^{-3} \mathrm{~d}^{-1}$ with a weekly biogas production of $226 \mathrm{~m}^{3}$. During this period there was again an increase in VFA to a final concentration of $28,000 \mathrm{mg} \mathrm{l}^{-1}$ when the trial finished. This was despite part of the digestate recycle being replaced with water when feeding restarted in week 29. Taking into account this load reduction, the overall specific biogas yield for the thermophilic digester was $0.67 \mathrm{~m}^{3} \mathrm{~kg} \mathrm{VS}_{\text {added }} \mathrm{d}^{-1}$ The digestate total solids averaged $5.4 \%$ with a VS content of $73.8 \%$. The $\mathrm{pH}$, alkalinity $\left(16400 \mathrm{mg} \mathrm{l}^{-1}\right)$ and ammonia concentrations $\left(5050 \mathrm{mg} \mathrm{l}^{-1}\right.$, reducing to $3600 \mathrm{mg} \mathrm{l}^{-1}$ from week 29) were similar to those in the mesophilic digester except that the $\mathrm{pH}$ of the digestate dropped to 6.8 at one point when the VFA concentration reached 44,625 $\mathrm{mg}$ $1^{-1}$. Key parameters as weekly average values are shown in Figure 5.

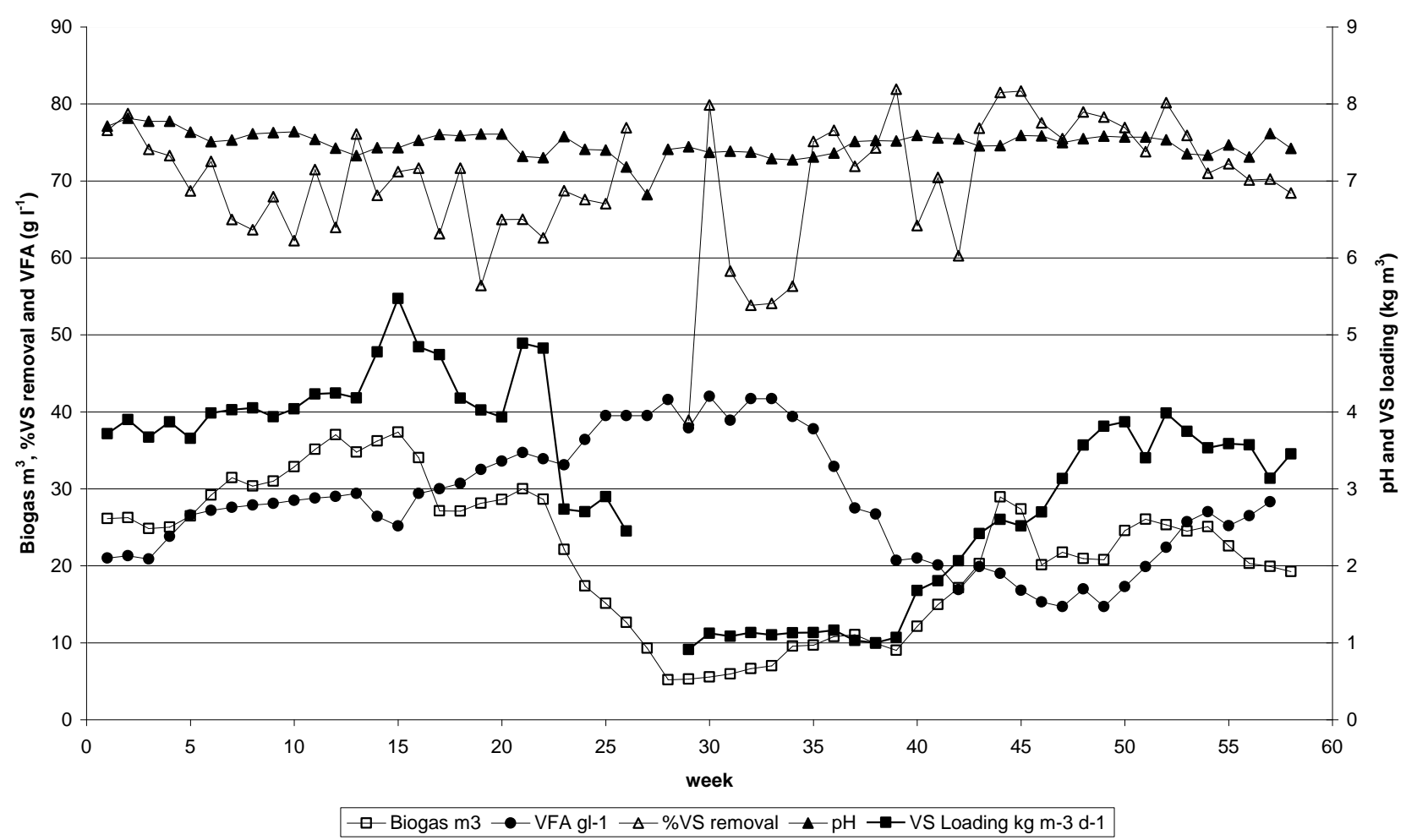

Figure 5. Key operational parameters from the mesophilic digester over the 58 week trial

Performance indicators. The $\mathrm{pH}$ in both the mesophilic and thermophilic digesters was relatively stable within narrow limits despite the large fluctuations in VFA concentrations, and proved to be a poor indicator of digester instability due to the delay in reaction time. This was due to the substantial buffering capability of the digestate. With the exception of one brief period in the thermophilic digester, the $\mathrm{pH}$ was within the limits of tolerance of methanogenic bacteria and good conversion was achieved. This indicates that, as long as the $\mathrm{pH}$ remained in this range, inhibition as a result of high VFA levels did not occur. This is similar to the self regulation seen in manure digesters where high free ammonia concentrations cause the accumulation of acetic and longer chain VFA as a result of acetogenic inhibition, but unless the magnitude of the accumulation is more than the system can withstand an equilibrium is attained where the VFA remain dissociated at the higher $\mathrm{pH}$ (Angelidaki, 1993).Both the mesophilic and thermophilic digesters had high alkalinity at $13,000 \mathrm{mg} \mathrm{l}^{-1}$ (range 9,250 to $19,125 \mathrm{mg} \mathrm{l}^{-1}$ ) and $16,400 \mathrm{mg} \mathrm{l}^{-1}$ (range $9,625-27,000 \mathrm{mg}$ 
$1^{-1}$ ) respectively. These are much higher than usually described in anaerobic digesters (typically 2000-4000 $\mathrm{mg} \mathrm{l}^{-1}$ ), due to the high nitrogen content of the food waste and the resulting high levels of ammonia. Concentrations of total VFA as high as 45,000 $\mathrm{mg} \mathrm{l}^{-1}$ (range 14,131-44,625 $\mathrm{mg} \mathrm{l}^{-1}$ ) were recorded in the thermophilic digester; in comparison the maximum VFA concentration recorded in the mesophilic digester was $28,000 \mathrm{mg} \mathrm{l}^{-1}$ (range 6,825-28,263 $\mathrm{mg} \mathrm{l}^{-1}$ ). The VFA concentration gave a rapid indication of the digester stability and acetic acid and propionic acids were the main VFA species that accumulated, with propionic acid seen mainly in the thermophilic digester but also in smaller concentrations under mesophilic conditions. Previous studies have indicated that VFA accumulation can been associated with a failure of the autotrophic methanogens which are able to use $\mathrm{CO}_{2}$ and $\mathrm{H}_{2}$ as precursors for methane production. Failure of this population can cause $\mathrm{H}_{2}$ partial pressures to increase leading to high levels of propionic acid (Wiegant and Zeeman, 1986). This has been associated with ammonia nitrogen concentrations above $3500 \mathrm{mg}^{-1}$ and also under these conditions an acetic acid product inhibition of butyric acid can be apparent (Ahring and Westermann, 1988). The carbon to nitrogen ratio of the digester feedstock (for both digesters) was 14:1 which is far lower than the 30:1 ratio often reported as optimal for digestion. During the digestion phase a substantial amount of the carbon is transformed into gaseous products leading to a reduction in the $\mathrm{C}: \mathrm{N}$ ratio in the digestate to around 8:1 in the mesophilic digester.

One of the aims of the trial was to attempt to increase the loading rate to the digesters to $6 \mathrm{~kg} \mathrm{VS} \mathrm{m}$ ${ }^{3} \mathrm{~d}^{-1}$ which has been achieved in other studies using BMW (Bolzonella, 2003). The mesophilic digester was started at a loading rate of around $3.5 \mathrm{~kg} \mathrm{VS} \mathrm{m}^{-3} \mathrm{~d}^{-1}$ which was gradually increased. Any increase above 4.0 tended to result in an increase in VFA and at loading above $4.5 \mathrm{~kg} \mathrm{VS} \mathrm{m}^{-3} \mathrm{~d}^{-}$

${ }^{1}$ was no additional biogas was produced. The loading pattern on the thermophilic digester was very similar increasing from around 3.7 to over $5.0 \mathrm{~kg} \mathrm{VS} \mathrm{m}^{-3} \mathrm{~d}^{-1}$; this rate was not sustainable however and feeding had to be suspended and the loading lowered as described above.

During the initial stages of the trial the thermophilic digester produced a higher biogas yield per $\mathrm{kg}$ of VS loaded with a maximum conversion rate of $1.1 \mathrm{~m}^{3} \mathrm{~kg}^{-1} \mathrm{VS}$ added averaged over weeks 44 and 45 of the trial; some of this yield may have been due to further conversion of accumulated VFA. The average biogas yield was $0.67 \mathrm{~m}^{3} \mathrm{~kg}^{-1} \mathrm{VS}$ added and the specific methane yield was $0.41 \mathrm{~m}^{3} \mathrm{~kg}^{-1}$ $\mathrm{VS}$ added. This was higher than biogas and methane yields in the mesophilic digester, which were 0.63 and $0.39 \mathrm{~m}^{3} \mathrm{~kg}^{-1} \mathrm{VS}$ added respectively. The maximum biogas yield of $0.8 \mathrm{~m}^{3} \mathrm{~kg}^{-1} \mathrm{VS}_{\text {added }}$ averaged over week 39 was also lower than in the thermophilic digester, but VFA levels were more stable in this digester. This suggests that if optimum conditions could be sustained, the thermophilic digestion process could produce a higher biogas yield than the mesophilic system. This is supported by the average VS reduction of the feedstock during the mesophilic digestion process which was $67 \%$ compared to a reduction of $70 \%$ in the thermophilic digester. There was no noticeable difference in the methane content of the biogas from the two digesters which averaged $58 \%$ in both. Trace gases were present at relatively low levels in the biogas with hydrogen sulphide at 1,300 to $1,700 \mathrm{ppm}$ and slightly more carbon monoxide in the thermophilic biogas (290 to $700 \mathrm{ppm}$ ) compared to the mesophilic (200 to $500 \mathrm{ppm}$ ).

\section{Mass balance}

The results allowed a mass balance to be constructed for the operation of the mesophilic digester (Figure 6) which showed that a tonne of kitchen waste could be converted into $170 \mathrm{~kg}$ of biogas containing $60 \mathrm{~kg}$ of methane, and $830 \mathrm{~kg}$ of digestate for potential use as fertiliser or soil conditioner. The results have led to the design of a demonstration-scale plant which will receive 5000 tonnes per year of kitchen and garden organic wastes. 


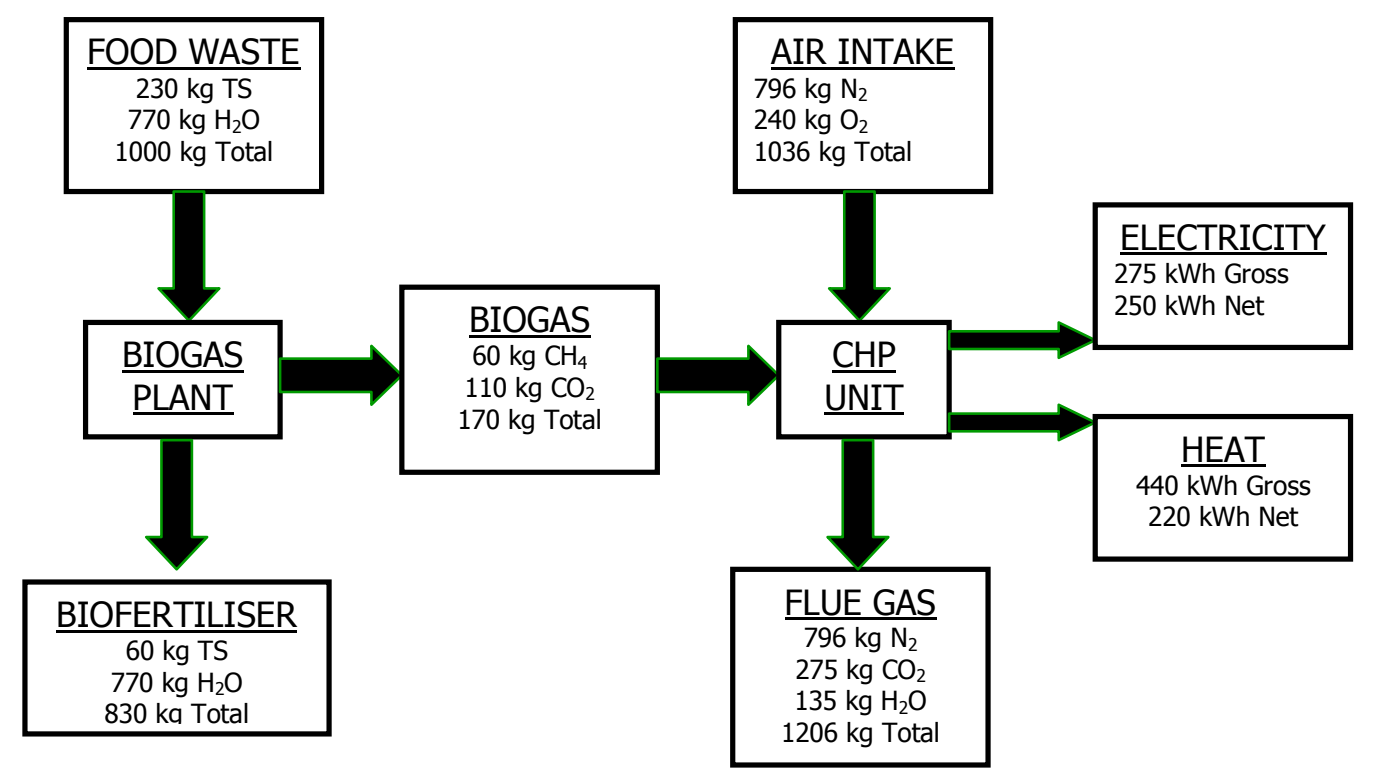

Figure 6. Mass balance around the mesophilic digester showing the energy gain and solid and liquid products from the digestion of $1000 \mathrm{~kg}$ of kitchen waste

\section{CONCLUSIONS}

The digestion of source segregated food waste under mesophilic conditions proved to be reasonably stable over the 58 week trial period, despite the high concentrations of volatile fatty acids and ammonia present in the digester liquor. VS destruction and specific gas yield were favourable with $67 \%$ of the organic solids being converted to biogas with yield of $0.63 \mathrm{~m}^{3} \mathrm{~kg}^{-1} \mathrm{VS}$ added at a methane concentration of 58\%. Although digestion under thermophilic conditions showed a better solids destruction and biogas yield the process was unstable, with volatile fatty acids accumulating up to $45,000 \mathrm{mg}^{-1}$ and causing the $\mathrm{pH}$ to drop to 6.8 with some loss of biogas production. In both cases the concentration of ammonia and VFA were reduced in the latter part of the trial by replacement of a part of the digestate recycle with fresh water.

\section{ACKNOWLEDGEMENTS}

This project was funded under the UK Landfill Tax Credit Scheme by Biffaward. Thanks are also due to Lisa Pritchard of Greenfinch for carrying out much of the laboratory analytical work.

\section{REFERENCES}

Angelidaki, I., Boe, K., and Ellegaard, L. (2005). Effect of operating conditions and reactor configuration on efficiency of full-scale biogas plants. Water Science and Technology, 52(1-2): 189-194.

Angelidaki, I., Ellegaard, L., and Ahring, B.K. (1993). A mathematical model for dynamic simulation of anaerobic digestion of complex substrates: focusing on ammonia inhibition. Biotechnology and Bioengineering, 42, 159-166.

Ahring, B. K. and Westermann, P. (1988). Product inhibition of butyrate metabolism by acetate and hydrogen in a thermophilic co-culture. Applied and Environmental Microbiology, 54, p2393-2398

Archer, E., Baddeley, A., Klein, A., Schwager, J., and Whiting, K. (2005). MBT: A Guide for Decision Makers Processes, Policies and Markets. Juniper Consulting Ltd, Uley, Gloucestershire, UK

Banks C. J. (1994). Anaerobic digestion of solid and high nitrogen content fractions of slaughterhouse wastes. In: Environmentally Responsible Food Processing. AIChE Symposium Series 90, 103-109

Bolzonella, D., Innocenti, L., Pavan, P., Traverso, P., and Cecchi, F. (2003). Semi-dry thermophilic anaerobic digestion of the organic fraction of municipal solid waste: Focusing on the start-up phase. Bioresource Technology 86(2): 123-129.

EC (1999) Council Directive 1999/31/EC of 26 April 1999 on the landfill of waste. OJ L 182, 16.7.1999, p.1-19

EC (2002). Regulation (EC) No 1774/2002 of the European Parliament and of the Council of 3 October 2002 laying down health rules concerning animal by-products not intended for human consumption. OJ L 273, 10.10.2002, p. 1

Gerardi, M. H. (2003). The Microbiology of Anaerobic Digesters. Hoboken, New Jersey, John Wiley \& Sons, Inc. 
Hartmann, H., and Ahring, B. K. (2005). A novel process configuration for anaerobic digestion of source-sorted household waste using hyper-thermophilic post-treatment. Biotechnology and Bioengineering 90(7): 830-837.

Hogg, D., Barth, J., Schleiss, K., and Favoino, E., (2007). Dealing with food wastes in the UK. Eunomia Research \& Consulting Ltd, Bristol, UK.

Jones, M. (2001). The Waste Away Scheme Phase Two: - a quantitative survey of the effectiveness of The Moray Council's waste minimisation scheme to reduce organic kitchen food waste going to landfill. Report prepared by Roslyn Associates, Kemnay, Aberdeenshire, UK

Mata-Alvarez, J., Ed. (2003). Biomethanization of the Organic Fraction of Municipal Solid Wastes. IWA Publishing, London.

Mtz-Viturtia, A., J. Mata-Alvarez, Cecchi, F. (1995). Two-phase continuous anaerobic digestion of fruit and vegetable wastes. Resources, Conservation and Recycling 13(3-4): 257-267.

APHA (2005). Standard Methods for the Examination of Water and Wastewater. 21st edn, American Public Health Association, American Wastewater Association and Water Environment Federation, Washington, D.C.

Wiegant, W. M., and Zeeman, G. (1986). The mechanism of ammonia inhibition in the thermophilic digestion of livestock wastes. Agricultural Wastes, 16, p243-253

Waste Not, Want Not (2002). A strategy for tackling the waste problem in England (2002). Strategy Unit, Cabinet Office, London. 